\title{
Quantitative Trait Loci Underlying Udder Morphology Traits in Dairy Sheep
}

\author{
B. Gutiérrez-Gil, M. F. El-Zarei, ${ }^{1}$ L. Alvarez, Y. Bayón, L. F. de la Fuente, F. San Primitivo, and J. J. Arranz ${ }^{2}$ \\ Departamento de Producción Animal, Facultad de Veterinaria, Universidad de León, 24071 León, Spain
}

\begin{abstract}
A genome scan was conducted on the basis of the daughter design to detect quantitative trait loci (QTL) influencing udder morphology traits in Spanish Churra dairy sheep. A total of 739 ewes belonging to 11 half-sib families were genotyped for 182 microsatellite markers covering 3,248.2 cM (Kosambi) of the ovine autosomal genome. Phenotypic traits included scores for 5 linear udder traits: udder depth, udder attachment, teat placement, teat size, and udder shape. Quantitative measurements for the QTL analysis were calculated for each trait from evaluation scores using within-family yield deviations corrected for fixed environmental effects. Joint analysis of all families using Haley-Knott regression identified 5 regions that exceeded the 5\% chromosome-wise significance threshold on chromosomes 7, 14, 15, 20, and 26. Based on the across-family results, a within-family analysis was carried out to identify families segregated according to the QTL and to estimate the QTL effect. The allelic substitution effect for individual families ranged from 0.47 to 1.7 phenotypic standard deviation units for udder shape on chromosome 15 and udder depth on chromosome 14, respectively. These QTL regions provide a starting point for further research aimed at the characterization of genetic variability involved in udder traits in Churra sheep. This paper presents the first report of a sheep genome scan for udder-related traits in a dairy sheep outbred population.
\end{abstract}

Key words: quantitative trait loci, dairy sheep, udder morphology, genome scan

\section{INTRODUCTION}

In dairy sheep, the most important functional traits are those related to udder morphology, because they determine the machine milking efficiency of the animal (Labussière, 1998) and have a substantial effect on its functional lifetime (Casu et al., 2003). Considering the great variability in udder morphology among breeds,

Received February 21, 2008.

Accepted May 16, 2008.

${ }^{1}$ Current address: Suez Canal University, Faculty of Agriculture, Department of Animal Production, 41522, Ismailia, Egypt.

${ }^{2}$ Corresponding author: jjarrs@unileon.es linear evaluation methods for udder morphology traits have been applied to several dairy sheep populations (Churra, Lacaune, Sardinian, Latxa, Manchega) with the aim of including these traits in the selection objectives of corresponding breeding programs (de la Fuente et al., 1996; Casu et al., 2006). Previously, breeding selection criteria were focused on production traits, which may have negatively affected mammary morphology traits by increasing udder depth and reducing teat verticality (Fernández et al., 1997). Thus, there is a need to introduce improved udder traits into ovine breeding schemes. Additionally, improved adaptation of udder morphology to machine milking may positively affect udder health by reducing subclinical and clinical mastitis in the animals (Fernández et al., 1997; MarieEtancelin et al., 2001; Bergonier et al., 2003; Legarra and Ugarte, 2005).

An understanding of the genetic architecture of complex traits may increase the genetic improvement obtained by classical selection. Genome screening for detection of QTL is an efficient approach to identify loci that influence the phenotypic variance of economically interesting traits. Compared with the extensive number of genome scan studies reported in dairy cattle for classical production (reviewed by Khatkar et al., 2004) and functional traits (e.g., udder morphology and mastitis resistance; Schrooten et al., 2000; Ashwell et al., 2005), the number of reported genome scan studies in dairy sheep is small (Casu, 2004). Genome scan studies in commercial dairy sheep have been limited by their low economic relevance, the restricted population of regionally exploited breeds, and the limited number of evaluated sires as a consequence of the recent implementation of artificial insemination. However, the family structure of the ovine dairy population is adequate for exploitation of molecular genetics to benefit animal breeding. In this work, we illustrate the use of the genome scan approach to map QTL underlying the genetic variation of udder morphology traits in a commercial population of dairy sheep.

\section{MATERIALS AND METHODOS}

\section{Pedigree Material}

The population available for the present study included a total of 739 ewes of the Spanish Churra 
dairy sheep selection scheme belonging to 11 half-sib families. The average family size was 67 ewes per ram, ranging from 30 (family 10) to 148 ewes (family 7). The animals involved in this daughter design were raised in 17 different flocks and linked through the use of artificial insemination.

\section{Phenotypic Data}

Udder depth, udder attachment, teat placement, teat size, and udder shape were assessed according to the 9-point linear scale described by de la Fuente et al. (1996). Ewes were scored by trained classifiers once per lactation period following the ANCHE Selection Scheme recording system (Fernández et al., 1997).

The quantitative measurements used in the association analysis were yield deviations (YD). These are the averages of the evaluation records of a ewe expressed as deviations from the population mean and corrected for fixed environmental effects. The following model was used for calculations of the YD:

$$
Y D_{i j k l}=Y_{i j k l}-\mu-R C_{i}-E d_{j}-M L_{k},
$$

where $Y D_{i j k l}=$ yield deviations corrected for the environmental factors included in the model; $Y_{i j k l}=$ the raw phenotypic record obtained during udder evaluation; $\mu=$ the population mean; $R C_{i}=$ the fixed effect of the qualification trial; $E d_{j}=$ the fixed effect of the age of the ewe (with 6 levels, from 1 to 5 and more than 6); and $M L_{k}=$ the fixed effect of the lactation phase in months (with 7 levels).

\section{Genotyping}

Following standard protocols, DNA was obtained from the semen of rams and whole blood of ewes (Sambrook et al., 1989). Microsatellite markers covering the ovine autosomal genome at regular intervals $(\sim 20 \mathrm{cM})$ were selected from the published ovine linkage maps (Maddox et al., 2001). Marker amplification was performed using the multiplex-PCR technique. Fluorescent labeling of primers allowed multiloading of different PCR reaction products on the ABIPrism 377 Semiautomatic Sequencer. Allele identification was performed with appropriate ABI software, GeneScan (3.7) and Genotyper (3.6; Applied Biosystems, Foster City, CA). The Morton test for heterogeneity (Morton, 1956) was applied to the 2-point logarithm of odds scores to detect residual genotyping anomalies. Linkage maps involving $182 \mathrm{mi}-$ crosatellites distributed along the ovine autosome were built using the CRIMAP package (Green et al., 1990). The CHROMPIC option of this software was used to detect multiple recombination events. This strategy al- lowed for the identification of new genotyping problems, thereby increasing the quality of the genetic records.

\section{QTL Analysis}

Information content extracted from the pedigree and genotypic data for the QTL analysis was computed in accordance with Coppieters et al. (1998). Linkage association analysis was performed using the HSQM package (Coppieters et al., 1998), which applies the regression method described by Knott et al. (1996). This program executes a QTL analysis by interval mapping that tests every centimorgan of the linkage map for the possible existence of a QTL according to the genotypes of the flanking markers for that position. When evidence for a significant effect was found in the across-family analysis, the position with the greatest F-value was considered as the most likely location of the QTL, and the within-family analysis was examined to identify the segregating families and to estimate the QTL size effect.

For each trait-chromosome combination, chromosome-wise $P$-values were estimated by 10,000 shuffles of the phenotypic data (Churchill and Doerge, 1994). Genome-wise $P$-values were determined from chromosome-wise $P$-values by applying the following Bonferroni correction, as suggested by de Koning et al. (1999): $p_{\text {genomewide }}=1-\left(1-p_{\text {chromosomewise }}\right)^{(1 / r)}$, where $r$ indicates the contribution of the chromosome to the total genome length. Ninety-five percent confidence intervals $(\mathbf{9 5 \%}$ CI) for the across-family QTL location and effect were calculated by the bootstrap method (Visscher et al., 1996).

\section{RESULTS}

The autosomal linkage map built for the Churra population, which spanned 3,248.2 Kosambi $\mathrm{cM}$ and included a total of 182 microsatellite markers distributed along the autosomal ovine chromosomes, has also been reported (Gutiérrez-Gil et al., 2008). A graphical representation of marker distribution and marker density can be found in Figure 1. The average information content per chromosome of the genome ranged between $41.48 \%$ (chromosome 8) and $74.86 \%$ (chromosome 6).

The across-family least squares interval mapping revealed 5 linkage associations exceeding the 5\% chromosome-wise significance threshold on chromosomes 7 (teat placement), 14 (udder depth), 15 (udder shape), 20 (udder depth), and 26 (udder attachment), which are detailed in Table 1 . None of the regions reached genome-wise significance. Only 1 significant region was identified per chromosome, and therefore no overlapping regions between QTL affecting different traits 
were observed. The $95 \%$ CI calculated by bootstrapping analysis for the significant associations comprised, in general, a very long fraction of the corresponding chromosome (Table 1). The shortest 95\% CI was obtained for the QTL that influenced udder depth on chromosome 20, which comprised the first $54 \mathrm{cM}$ from the centromeric end.

Tabulated values for the F-distributions obtained from the within-family analysis were used to determine the significance of effects $(P<0.05)$. For each across-family significant QTL, family size, position of the maximum test statistic, and allelic substitution effect (expressed in both linear scale points and phenotypic SD units) are summarized in Table 1 for the segregating families. Only 1 family was significant for the QTL detected on chromosomes 14 and 20 in the within-family analysis, whereas 2 (chromosome 7 ) and 3 families (chromosomes 15 and 26) segregated for the other QTL effects.

\section{Chromosome 7}

The greatest significant association identified by the regression analysis was the QTL on chromosome 7 for teat placement. The most likely position suggested by the across-family analysis for this QTL was at $17 \mathrm{cM}$ from the centromeric end of the chromosome, flanked by markers BM3033 and BMS528 (Figure 2). The test statistic profile for teat placement on this chromosome showed a secondary peak at position 42 to 44 $\mathrm{cM}$, which also exceeded the $5 \%$ significance threshold. The effect of teat placement on this chromosome was accompanied by a parallel behavior of the udder shape statistical profile, although this effect did not reach chromosome-wise significance. Results from the within-family analysis showed certain discrepancies regarding QTL position among the 2 segregating families. For example, the peak position for family 10 was located on the proximal half of the chromosome, whereas the peak test statistics for teat placement were located at the distal end of the linkage map for family 6 . For these families, the allelic substitution effect ranged from -0.216 to -0.448 points on the linear scale, which corresponds to approximately 0.7 to 1.5 phenotypic SD units (Table 1).

\section{Chromosome 15}

The peak test statistic for udder shape was located at the centromeric end of chromosome 15, between markers MCMA16 and BR3510. The QTL positions suggested by the within-family analyses for the 3 segregating families for this effect (families 1,5 , and 7) were all within the first marker interval of the linkage

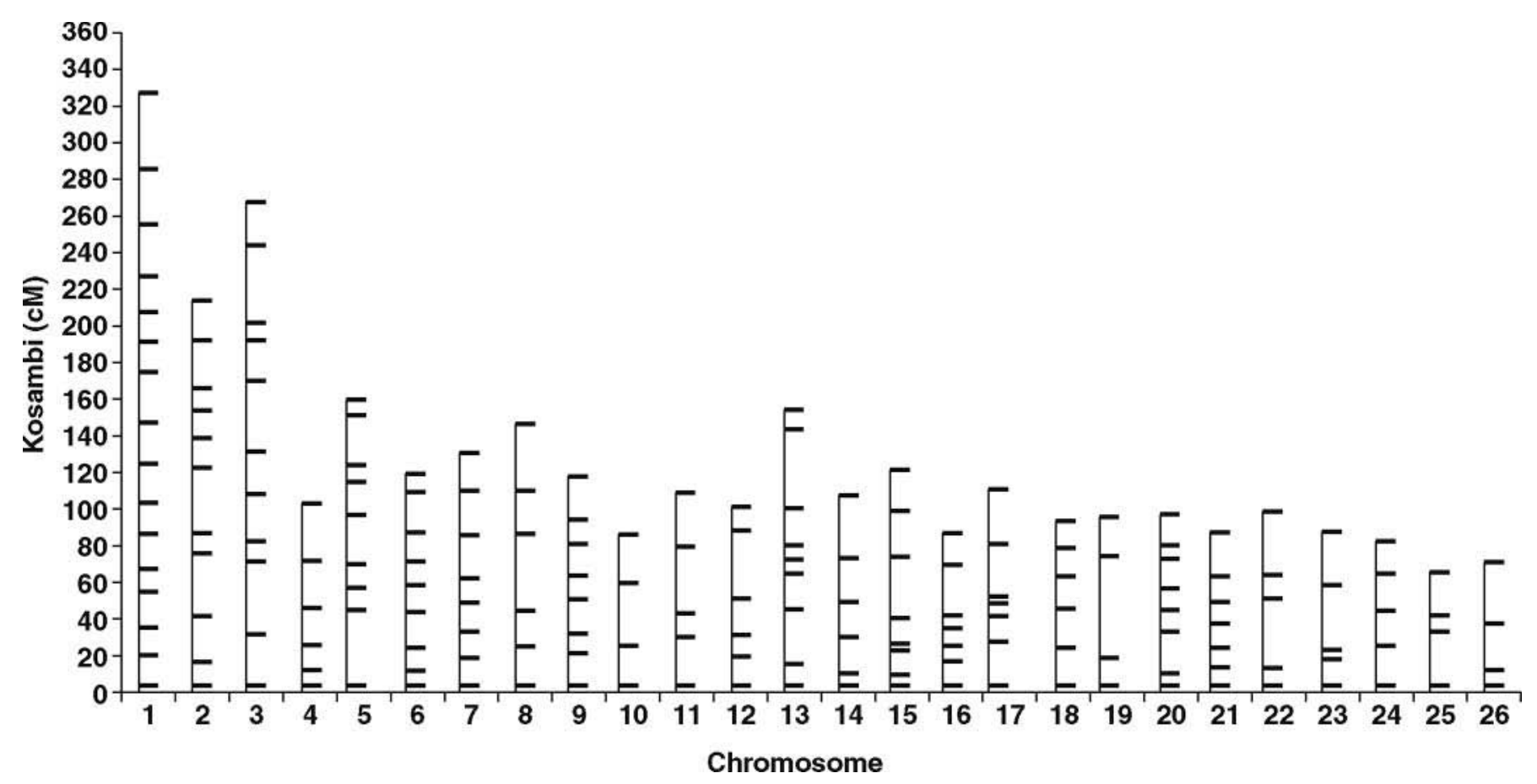

Figure 1. Graphical representation of marker distribution and marker density for the 26 autosomal chromosomes analyzed in this work. Markers on a given chromosome are represented as horizontal lines along the length of the chromosome. 
Table 1. Characterization of QTL influencing udder morphology traits that exceed the 5\% chromosome-wise significance threshold in the commercial population of Spanish Churra dairy sheep analyzed in this study ${ }^{1}$

\begin{tabular}{|c|c|c|c|c|c|c|}
\hline \multicolumn{4}{|c|}{ Across-family analysis } & \multicolumn{3}{|c|}{ Within-family analysis } \\
\hline $\mathrm{Chr}^{2}$ & $\begin{array}{l}\text { Trait and position } \\
(95 \% \mathrm{CI})^{4}\end{array}$ & Flanking interval $^{5}$ & $P$-value ${ }^{6}$ & $\begin{array}{l}\text { Segregating } \\
\text { families } \\
\text { (family size) }\end{array}$ & Position, ${ }^{3} \mathrm{cM}$ & $\begin{array}{l}\text { Size effect }{ }^{7} \\
\text { (SD units) }\end{array}$ \\
\hline 7 & $\begin{array}{l}\text { Teat placement } \\
17 \mathrm{cM} \\
\text { ( } 2 \text { to } 137 \mathrm{cM})\end{array}$ & [BM3033-BMS528] & 0.0136 & $\begin{array}{r}6(76) \\
10(30)\end{array}$ & $\begin{array}{r}131 \\
44\end{array}$ & $\begin{array}{l}-0.216(0.735) \\
-0.448(1.525)\end{array}$ \\
\hline 15 & $\begin{array}{l}\text { Udder shape } \\
1 \mathrm{cM} \\
\text { (1 to } 128 \mathrm{cM})\end{array}$ & [MCMA16-BR3510] & 0.036 & $\begin{array}{l}1(75) \\
5(101) \\
7(148)\end{array}$ & $\begin{array}{r}12 \\
9 \\
2\end{array}$ & $\begin{array}{l}-0.45(1.5) \\
-0.18(0.59) \\
-0.141(0.47)\end{array}$ \\
\hline 20 & $\begin{array}{l}\text { Udder depth } \\
8 \mathrm{cM} \\
\text { (1 to } 54 \mathrm{cM})\end{array}$ & [INRA132-DYA] & 0.016 & $5(101)$ & 5 & $-0.141(0.52)$ \\
\hline
\end{tabular}

${ }^{1}$ The results for each significant association detected in the across-family analysis and the within-family analyses are shown for the corresponding segregating families $(P<0.05$ chromosome-wise).

${ }^{2}$ Chromosome number.

${ }^{3}$ Positions (cM Haldane) of the chromosome where the maximum F-statistic value was obtained in the across- and within-family analyses, respectively.

${ }^{4}$ The confidence interval (95\%) obtained by bootstrapping analysis (Visscher et al., 1996) is shown in parentheses.

${ }^{5}$ Markers flanking the position of the maximum F-statistic, according the across-family analysis.

${ }^{6}$ Chromosome-wise $P$-value obtained by the permutation test (Churchill and Doerge, 1994) for the chromosomal position where the maximum F-statistic value was obtained in the across-family analysis.

${ }^{7}$ Magnitude of the allelic substitution effect for each segregating family is expressed in linear scale units. This parameter expressed in standard deviation units of the corresponding trait is shown in parentheses.

map. The allelic substitution effect in these families had values ranging from 0.47 to 1.5 phenotypic standard deviation units.

\section{Chromosome 20}

The most significant test statistics for udder depth were identified at the centromeric end of chromosome 20 (Figure 3), between markers INRA132 and DYA. The statistical profile for udder depth suggested the existence of a secondary peak at position $27 \mathrm{cM}$, between markers DYA and BM1258, which exceeded the chromosome-wise significance threshold $(P=0.0236)$. The statistical profile for udder attachment showed traces of linkage parallel to the second peak of the udder depth curve, although this linkage was far from significant. The allelic substitution effect for the single family segregating for this QTL was approximately 0.5 phenotypic standard deviation units.

\section{Chromosome 26}

The QTL effect detected at the distal end of chromosome 26 for udder attachment was mainly due to the effect seen in 3 out of the 11 families considered in the analysis. For families 5 and 11, the suggested positions for the putative QTL mapped to the interval [CSSM43-BM203], whereas the greatest peak for family 1 was detected in the next upstream marker interval, [BM6526-CSSM43]. The allelic substitution effect for the 3 families was about 0.7 phenotypic standard deviation units.

\section{Chromosome 14}

The distal end of chromosome 14 showed a significant linkage association with udder attachment. Only the sire of family 4 , which is the smallest half-sib group included in our analysis, showed evidence of being heterozygous for this QTL. The allelic substitution in this family was considerably high (1.7 phenotypic SD units).

Apart from the previously mentioned effects, traces of linkage were found on other chromosomes, although their $P$-values were only suggestive $(P<0.10)$. These traces of linkage were found on chromosomes 4 and 23 for udder shape; chromosomes 6, 8, and 14 for udder depth; chromosome 10 for teat placement; and chromosome 22 for teat size (results not shown). 


\section{DISCUSSION}

Results of this study provide evidence of quantitative trait loci underlying udder morphology traits segregating within a commercial population of Spanish Churra dairy sheep. Although a greater genotyping effort is required than a granddaughter design, the fitness of the daughter design applied to this outbred population has been shown by the high-quality linkage map that was constructed (Gutiérrez-Gil et al., 2008) and the discovery of several QTL that influence economically interesting traits in dairy sheep (Gutiérrez-Gil et al., 2007; our unpublished data).
The across-family regression analysis identified a total of 5 chromosomal regions at the $5 \%$ chromosomewise significance level across the whole ovine autosome (Table 1). Although these regions did not reach the $5 \%$ genome-wise significance level calculated through a Bonferroni correction (de Koning et al., 1999), 4 of the regions reached the suggestive linkage level suggested by Lander and Kruglyak (1995). Many authors have stressed the importance of reporting suggestive linkage associations in livestock species and suggested that stringent corrections, such as Bonferroni's, are not suitable for livestock linkage analysis due to the limited power to discover segregating QTL (Lander and

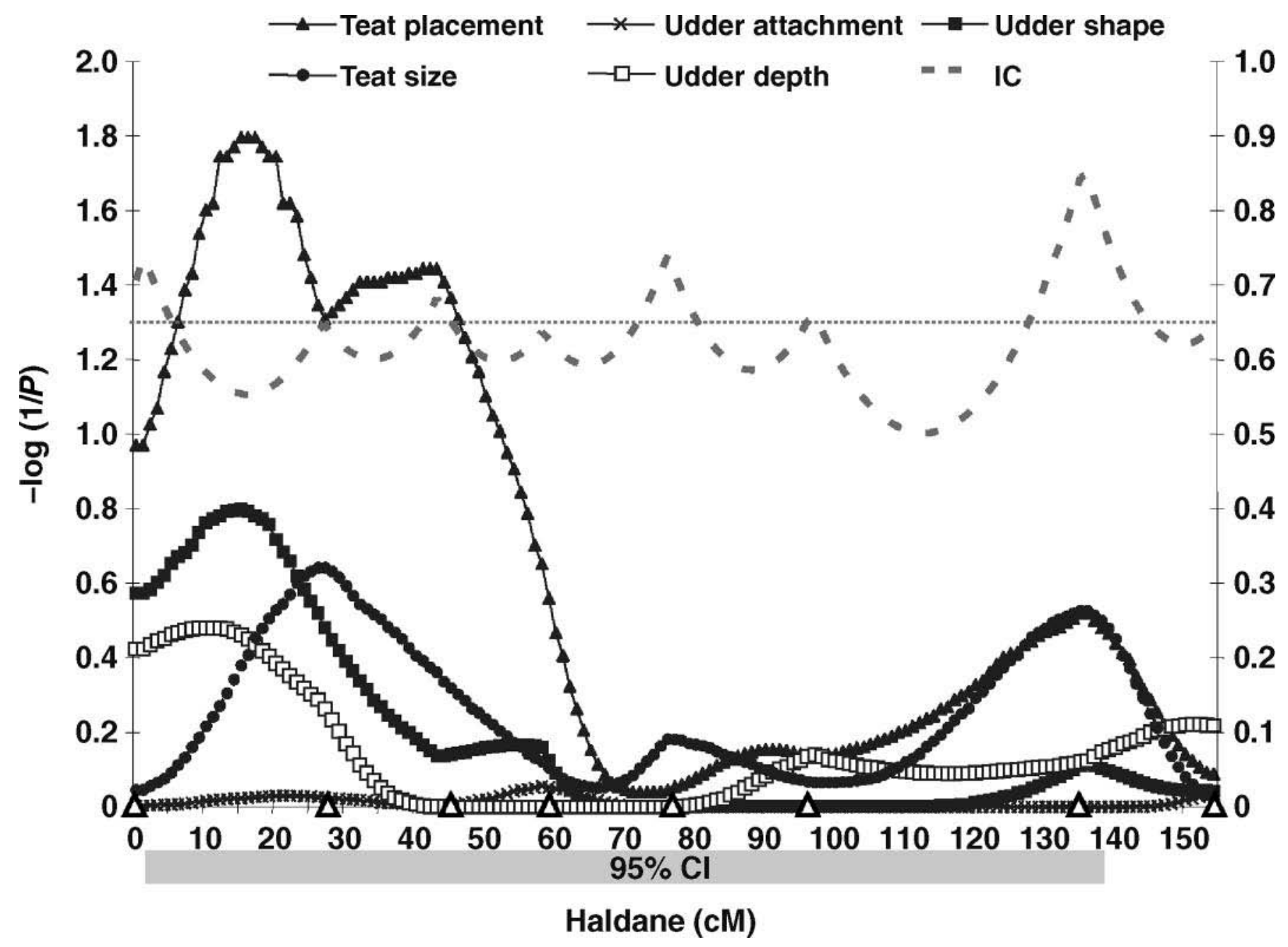

Figure 2. Across-family statistical profiles for the chromosome-wise significant QTL $(P<0.05)$ identified by this study for udder morphology traits on chromosome 7 . The $\log (1 / P)$ across the linkage map is represented on the y-axis, where $P=$ the associated chromosomewise $P$-value determined by permutation testing. The horizontal dashed line represents the $5 \%$ chromosome-wise significance threshold. Information content (IC) obtained along the linkage groups is represented on the right y-axis. Beginning at the centromeric end, the triangles on the $\mathrm{x}$-axis indicate the relative positions of the markers BM3033, BMS528, BRN, BMS861, BMS419, BMS1620, ILSTS005, and ILSTS020. The confidence interval (95\% CI) calculated by bootstrapping analysis for the teat placement QTL is shown as a dark box at the bottom of the figure. 


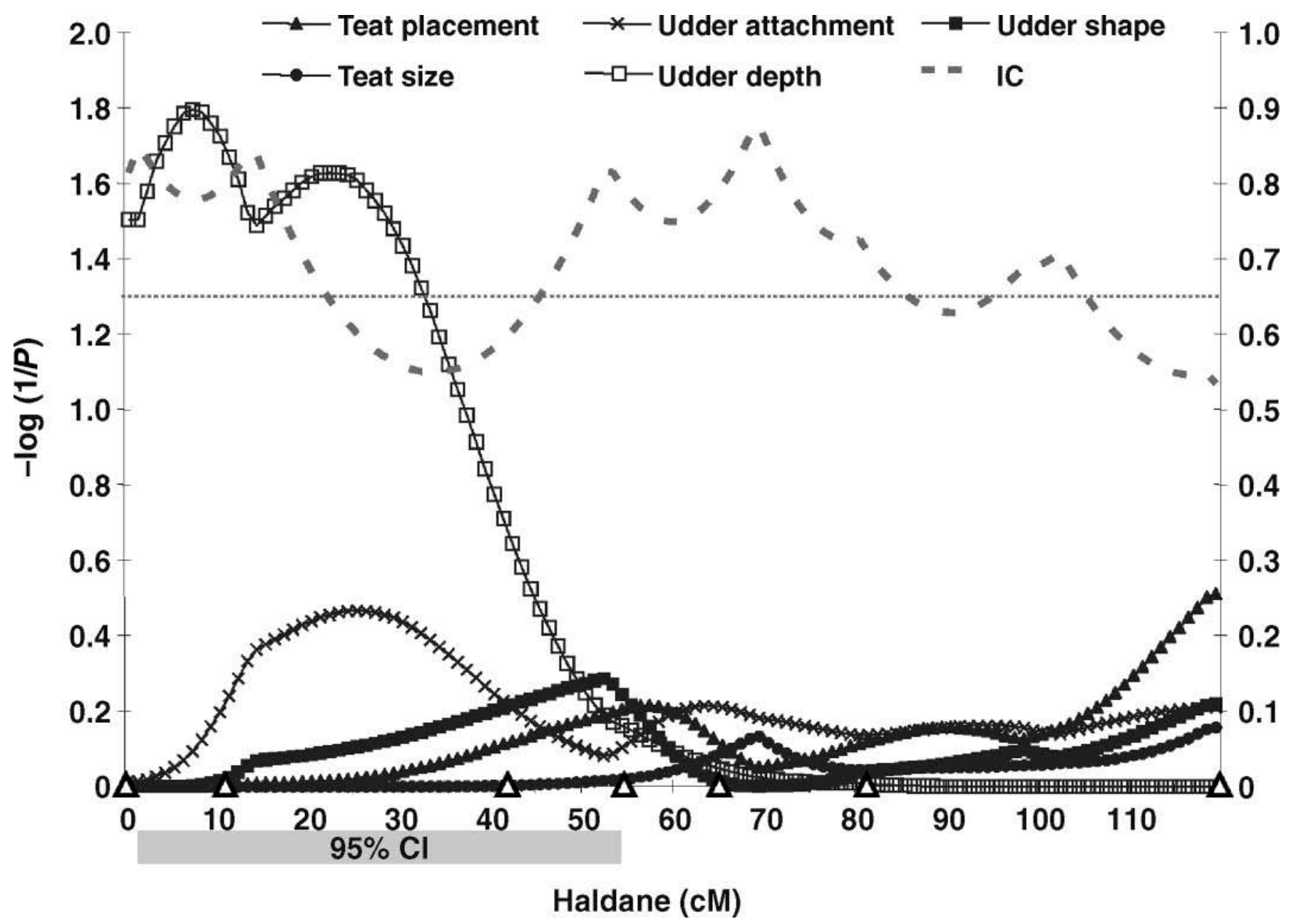

Figure 3. Across-family statistical profiles for the chromosome-wise significant QTL $(P<0.05)$ identified by this study for udder morphology traits on chromosome 20 . The $\log (1 / P)$ across the linkage map is represented on the y-axis, where $P=$ the associated chromosomewise $P$-value determined by permutation testing. The horizontal dashed line represents the $5 \%$ chromosome-wise significance threshold. Information content (IC) obtained along the linkage groups is represented on the right y-axis. Beginning at the centromeric end, the triangles on the $\mathrm{x}$-axis indicate the relative positions of the markers, INRA132, DYA, BM1258, OLADRBPS, BP34, BM1905, and MCMA23. The confidence interval (95\% CI) calculated by bootstrapping analysis for the teat placement QTL is shown as a dark box at the bottom of the figure.

Kruglyak, 1995; Weller et al., 1998). As expected for results derived from a preliminary scan, the $95 \%$ CI intervals calculated for the QTL identified here comprised most of the chromosomal length. According to a principal component analysis performed with the SAS (1998) package (results not shown), we can consider 2.5 independent analyzed traits. For the 5\% chromosomewise significance level, the number of significant tests expected by chance alone at the suggestive level in our experiment would be 2.6 , whereas 5 significant associations were observed. Hence, evidence exists in favor of genuine QTL for udder morphology traits segregating in the studied population of Churra sheep.

We adapted the method proposed by Weller et al. (1990) to our experimental design (number of analyzed ewes and families, marker density, and marker informativeness) to estimate the power to detect QTL in this population of Churra sheep. This method predicted the identification of approximately $30 \%$ of QTL with 2 alleles of equal frequency to have a magnitude effect of 0.3 phenotypic standard deviation units and to affect a trait with heritability by 0.3 . This estimation was performed assuming a type I error rate of 0.05 and $10 \%$ recombination between a marker and the QTL. The limited power of our design may explain the restricted number and significance level of the QTL detected at the whole-population level, suggesting that a substantial proportion of genuine QTL may not have been identified. Hence, further research that builds upon the significant associations reported here should focus on confirmation of these QTL by examining additional daughters of the segregating families. It is 
Table 2. Putative correspondence between the QTL found in the present study and other similar QTL reported in other sheep populations and dairy cows

\begin{tabular}{|c|c|c|c|c|c|c|}
\hline \multicolumn{2}{|c|}{$\begin{array}{l}\text { QTL detected in } \\
\text { Churra sheep }\end{array}$} & \multicolumn{2}{|c|}{ QTL detected in other sheep studies } & \multicolumn{3}{|c|}{ QTL detected in the orthologous region of cow } \\
\hline $\mathrm{Chr}^{1}$ & $\begin{array}{l}\text { Trait } \\
\text { [flanking } \\
\text { markers] }\end{array}$ & $\begin{array}{l}\text { Trait } \\
\text { [flanking } \\
\text { markers] }\end{array}$ & $\begin{array}{l}\text { Population }{ }^{2} \\
\text { and reference }\end{array}$ & $\mathrm{Chr}^{1}$ & $\begin{array}{l}\text { Trait } \\
\text { [flanking } \\
\text { markers] }\end{array}$ & Reference \\
\hline \multirow[t]{2}{*}{ OAR7 } & \multirow[t]{2}{*}{$\begin{array}{l}\text { Teat placement } \\
\text { [BM3033-BMS528] }\end{array}$} & & & \multirow[t]{2}{*}{ BTA10 } & $\begin{array}{l}\text { Front teat placement } \\
\text { [BRRIBOold-BMS861] }\end{array}$ & Schrooten et al. (2000) \\
\hline & & & & & $\begin{array}{l}\text { Milking speed } \\
\text { [TGLA4] }\end{array}$ & Hiendleder et al. (2003) \\
\hline OAR14 & $\begin{array}{l}\text { Udder depth } \\
\text { [MCM104- } \\
\text { BM6507] }\end{array}$ & & & BTA18 & $\begin{array}{l}\text { Milking speed } \\
\text { [BM2078-TGLA227] }\end{array}$ & Hiendleder et al. (2003) \\
\hline OAR15 & $\begin{array}{l}\text { Udder shape } \\
\text { [MCMA16-BR3510] }\end{array}$ & & & BTA15 & $\begin{array}{l}\text { Udder depth } \\
\text { [BMS2684-HBB] } \\
\text { Udder cleft } \\
\text { [HBB-ILSTS061] } \\
\text { Udder composite index } \\
\text { [HBB-ILSTS061] }\end{array}$ & Ashwell et al. (2005) \\
\hline \multirow[t]{4}{*}{ OAR20 } & \multirow{4}{*}{$\begin{array}{l}\text { Udder depth } \\
\text { [INRA132-DYA] }\end{array}$} & \multirow{4}{*}{$\begin{array}{l}\text { Udder lateral height } \\
\text { Degree of separation } \\
\text { of the } 2 \text { halves } \\
\text { [INRA132-BM1258] }\end{array}$} & \multirow{4}{*}{$\begin{array}{l}\text { Sarda } \times \\
\text { Lacaune BC } \\
\text { Casu (2004) }\end{array}$} & \multirow[t]{4}{*}{ BTA23 } & Front teat placement & Ashwell et al. (2005) \\
\hline & & & & & [BM1258-MGTG7] & \\
\hline & & & & & $\begin{array}{l}\text { Front udder } \\
\text { attachment } \\
\text { [CSSM5-BM1258] } \\
\text { Udder composite index }\end{array}$ & Ashwell et al. (2005) \\
\hline & & & & & $\begin{array}{l}\text { [CSSM5-BM1258] } \\
\text { Fore udder } \\
\text { attachment } \\
\text { [RM033] }\end{array}$ & Schrooten et al. (2000) \\
\hline OAR26 & Udder attachment & Udder depth & $\begin{array}{l}\text { Sarda } \times \\
\text { Lacaune BC }\end{array}$ & BTA27 & Udder depth & Schrooten et al. (2000) \\
\hline
\end{tabular}

${ }^{1} \mathrm{Chr}=$ chromosome. $\mathrm{OAR}=$ Ovis aries $; \mathrm{BTA}=$ Bos taurus.

${ }^{2} \mathrm{BC}=$ backcross design, for the Sarda $\times$ Lacaune population; GDD $=$ granddaughter design, for the Lacaune commercial population.

also worth comparing our results with QTL reported in other studies for udder morphology traits. A summary of putative correspondence between the significant associations identified in Churra sheep and those reported in other ovine populations is presented in Table 2. The QTL for udder morphology traits identified in the corresponding bovine orthologous region are also indicated in Table 2.

The most significant effect identified by this study was at the proximal end of chromosome 7 affecting teat placement (Figure 2), which is one of the most important traits in terms of the adaptation of the ewe to machine milking. The optimal traits for machine milking related to completely vertical teats and mini- mal cistern height (de la Fuente et al., 1996). In this case, the most likely positions suggested by the withinfamily analyses for the 2 segregating families (44 and $131 \mathrm{cM}$ for families 10 and 6, respectively) may be the result of the different levels of informativeness of the markers in the 2 segregating families. The sire of family 10 was not informative for ILSTS005, located at the distal end of chromosome 7 and flanking the QTL position suggested for family 6 . Teat placement is one of the most influential traits affecting the global score, which defines the udder shape traits in the Churra population. Positive genetic correlations exist between these 2 traits $\left(r_{g}=0.96\right.$; Fernández et al., 1997), which may explain the tendency of the udder shape statisti- 
cal profile to accompany the significant effects for teat placement on chromosome 7 , although without exceeding the chromosome-wise significance threshold (Figure 2). Up to now, no other QTL for udder morphology traits have been described on ovine chromosome 7. The bovine orthologous region to this QTL, which is located on bovine chromosome 10, has been found to harbor several QTL for udder-related traits (Table 2).

Two significant regions, located on chromosomes 14 and 20, were found to be associated with udder depth. This is an important trait in dairy sheep breeding schemes because it is likely to have been negatively affected by initial selection which focused on production traits. Furthermore, udder depth seems to have a low but positive correlation with somatic cell score (Fernández et al., 1997; Legarra and Ugarte, 2005). The QTL influencing udder depth on chromosome 20 was the second most significant association detected by our analysis (Figure 3) and the one showing the shortest 95\% CI (53 cM long). The allelic substitution effect for this trait was approximately 0.5 phenotypic standard deviation units for the single segregating family. Support for the location and genuine nature of this chromosome 20 QTL is obtained from the Sarda $\times$ Lacaune backcross population described by Carta et al. (2002), in which QTL for udder lateral height and the degree of separation of the 2 halves are located within the marker interval [INRA132-BM1258] (Casu, 2004). The detection of coincident QTL for correlated traits in these 2 separate populations suggests that the first third of ovine chromosome 20 should be a target of future research related to udder conformation in sheep. The orthologous region of this QTL, on bovine chromosome 23, has been reported to be associated with a variety of udder-related traits in dairy cows (Table 2). The chromosome-wise significant association identified for udder traits on chromosome 14 showed lower statistical significance, possibly because only 1 family was segregated for this QTL. The size of the effect estimated for this QTL is large (1.7 phenotypic SD units); the size of the segregating family (64 ewes) may have overestimated the magnitude of the real effect.

The proximal end of chromosome 15 was associated with the global trait udder shape. Although this trait simultaneously assesses several udder traits such as symmetry, depth, attachment, teat position, and size (de la Fuente et al., 1996), none of these traits showed significant effects on this chromosome. The QTL position estimated for the 3 segregating families was found proximal to the centromeric end of the chromosome. As indicated in Table 2, linkage associations for several udder-related traits have been identified in the orthologous region of the bovine genome.
Another suggestive linkage association identified in the analysis of the whole population was located in the last third of chromosome 26 and affected udder attachment. The most likely position suggested for families 5 and 11 , by the within-family analysis, was located in the last marker interval of this chromosome, [CSSM43BM203], whereas the QTL position suggested for family 1 was in the upstream marker interval. Although the 3 segregating sires were found to be heterozygous for the 3 distal markers analyzed in this chromosome, the low density of markers analyzed in the second half of this linkage group may explain the discrepancy regarding the QTL position for the segregating families. Importantly, marker CSSM43 was found to flank the peak of the statistical profiles for the 3 segregating families. Support for this association is found in the study reported by Casu (2004), which identified 2 overlapping QTL for udder depth and udder height within the marker interval [BM6526-CSSM43]. Marker CSSM43 has also been found to be associated with udder depth in a purebred Lacaune population under the basis of a granddaughter design (F. Barillet, INRA, France; personal communication). A QTL for udder depth has also been described in dairy cattle in the orthologous region (Schrooten et al., 2000).

Because the animals analyzed in the present study are part of a resource population analyzed for other economical traits in dairy sheep, (Gutiérrez-Gil et al., 2007; our unpublished data), putative pleiotropic genetic effects could be identified. After comparison of results for different groups of traits, we did not find any coincidence between the QTL and the segregating families identified for mammary traits and other phenotypes under study. Hence, the QTL identified in this population for SCS on chromosome 20 (Gutiérrez-Gil et al., 2007) was segregating in different families and was located at the opposite chromosomal end of the udderrelated QTL reported in this work. Regarding the QTL affecting milk traits, the effect detected on chromosome 15 for udder shape maps to the same chromosomal region than a putative QTL for protein percentage (B. Gutiérrez-Gil, unpublished data). However, the lack of coincidence between the families segregating for these 2 QTL, together with the low correlation reported between these 2 traits (Fernández et al., 1997), suggest that these effects are the result of different segregating loci in Churra sheep.

Based on the previously mentioned data, we believe that the QTL reported here provide very useful information for the dairy sheep research community. The regions described in this paper represent primary information of QTL for udder morphology in an outbred population and can serve as a required starting point 
for future fine-mapping studies aimed at the identification of genetic variants directly associated with udder traits in Churra dairy sheep.

The regions reported here may be considered as candidate regions for future research, of which the first stage should focus on confirmation and redefinition of these QTL positions. If the QTL positions are confirmed, identification and detailed study of the candidate genes would follow. The increasing amount of information derived from bovine genome sequencing and annotation projects and newly available resources on sheep genomics (Dalrymple et al., 2007; Di Meo et al., 2007) will be of great assistance to speed up the identification of allelic variants underlying trait effects which are detected by scans of the ovine genome, such as the scan presented here.

\section{CONCLUSIONS}

Five QTL influencing udder morphology traits were detected at the $5 \%$ chromosome-wise level on sheep chromosomes 7, 14, 15, 20 and 26. Future efforts will focus in the confirmation and redefinition of the linkage associations reported here. These results have been found in a commercial population on Churra sheep. Hence, molecular information derived from this work may potentially be included in the future within the breeding program of this population.

\section{ACKNOWLEDGMENTS}

This work was supported by the Spanish Ministry of Education and Science (Project 1FD97-0225) and the European Union through the project genesheepsafety (QLK5-2000-00656). Beatriz Gurtiérrez-Gil is funded by the Juan de la Cierva Program of the Spanish Ministry of Education and Science.

\section{REFERENCES}

Ashwell, M. S., D. W. Heyen, J. I. Weller, M. Ron, T. Sonstegard, C. Van Tassell, and H. Lewin. 2005. Detection of quantitative trait loci influencing conformation traits and calving ease in HolsteinFriesian cattle. J. Dairy Sci. 88:4111-4119.

Bergonier, D., R. De Cremoux, R. Rupp, G. Lagriffoul, and X. Berthelot. 2003. Mastitis of dairy small ruminants. Vet. Res. 34:689-716.

Carta, A., F. Barillet, D. Allain, Y. Amigues, B. Bibé, L. Bodin, S. Casu, E. Cribiu, J. Elsen, A. Fraghi, L. Grune, P. Jacquiet, S. Ligios, C. Marie-Etancelin, L. Mura, G. Piredda, R. Rupp, S. Sanna, A. Scala, L. Schilber, and S. Casu. 2002. QTL detection with genetic markers in a dairy sheep backcross Sarda $\times$ Lacaune resource population. Pages 211-214 in Proc. 7th World Congr. Genet. Appl. Livest. Prod. Montpellier, France. INRA, CastanetTolosan, France.
Casu, S. 2004. Recherche de QTL contrôlant la cinétique de l'emission du lait et la morphologie de la mamelle chez les brebis laitières. $\mathrm{PhD}$ Thesis. Institut National Agronomique, Paris, France.

Casu, S., C. Marie-Etancelin, L. Schibler, E. Cribiu, L. Mura, T. Sechi, A. Fraghi, A. Carta, and F. Barillet. 2003. A genome scan to identify quantitative trait loci affecting udder morphology traits in dairy sheep. Article no. 2-19 in Proc. Int. Workshop on Major Genes and QTL in Sheep and Goat (IWMGQSG), Toulouse, France. INRA, Castanet-Tolosan, France.

Casu, S., I. Pernazza, and A. Carta. 2006. Feasibility of a linear scoring method of udder morphology for the selection scheme of Sardinian sheep. J. Dairy Sci. 89:2200-2209.

Churchill, G., and R. Doerge. 1994. Empirical threshold values for quantitative trait mapping. Genetics 138:963-971.

Coppieters, W., A. Kvasz, F. Farnir, J. J. Arranz, B. Grisart, M. Mackinnon, and M. Georges. 1998. A rank-based nonparametric method for mapping quantitative trait loci in outbred half-sib pedigrees: Application to milk production in a granddaughter design. Genetics 149:1547-1555.

Dalrymple, B. P., E. F. Kirkness, M. Nefedov, S. McWilliam, A. Ratnakumar, W. Barris, S. Zhao, J. Shetty, J. F. Maddox, M. O'Grady, F. Nicholas, A. M. Crawford, T. Smith, P. J. de Jong, J. McEwan, V. H. Oddy, and N. E. Cockett; International Sheep Genomics Consortium. 2007. Using comparative genomics to reorder the human genome sequence into a virtual sheep genome. Genome Biol. 8:R152.

de Koning, D. J., L. L. Janss, A. P. Rattink, P. A. van Oers, B. J. de Vries, M. A. Groenen, J. J. van der Piel, P. N. de Groot, E. W. Brascamp, and J. A. van Arendonk. 1999. Detection of quantitative trait loci for backfat thickness and intramuscular fat content in pigs (Sus scrofa). Genetics 152:1679-1690.

de la Fuente, L. F., G. Fernández, and F. San Primitivo. 1996. A linear evaluation system for udder traits of dairy ewes. Livest. Prod. Sci. 45:171-178.

Di Meo, G. P., A. Perucatti, S. Floriot, H. Hayes, L. Schibler, R. Rullo, D. Incarnato, L. Ferretti, N. Cockett, E. Cribiu, J. L. Williams, A. Eggen, and L. Iannuzzi. 2007. An advanced sheep (Ovis aries, $2 \mathrm{n}=54$ ) cytogenetic map and assignment of 88 new autosomal loci by fluorescence in situ hybridization and R-banding. Anim. Genet. 38:233-240.

Fernández, G., J. A. Baro, and L. F. De La Fuente. 1997. Genetic parameters for linear udder traits of dairy ewes. J. Dairy Sci. 80:601-605.

Green, P., K. Falls, and S. Crooks. 1990. Documentation for CRIMAP, version 2.4. Washington University School of Medicine, St Louis, MO.

Gutiérrez-Gil, B., J. J. Arranz, M. F. El-Zarei, L. Álvarez, S. Pedrosa, F. San Primitivo, and Y. Bayón. 2008. A male linkage map constructed for QTL mapping in Spanish Churra sheep. J. Anim. Breed. Genet. 125:201-204.

Gutiérrez-Gil, B., M. F. El-Zarei, Y. Bayón, L. F. de la Fuente, F. San Primitivo, and J. J. Arranz. 2007. Genome scan analysis for detection of QTL influencing somatic cell score in dairy sheep. J. Dairy Sci. 90:422-426.

Hiendleder, S., H. Thomsen, N. Reinsch, J. Bennewitz, B. LeyheHorn, C. Looft, N. Xu, I. Medjugorac, I. Russ, C. Kühn, G. A. Brockmann, J. Blümel, B. Brenig, F. Reinhardt, R. Reents, G. Averdunk, M. Schwerin, M. Förster, E. Kalm, and G. Erhardt. 2003. Mapping of QTL for body conformation and behavior in cattle. J. Hered. 94:496-506.

Khatkar, M. S., P. C. Thomson, I. Tammen, and H. W. Raadsma. 2004. Quantitative trait loci mapping in dairy cattle: Review and meta-analysis. Genet. Sel. Evol. 36:163-190.

Knott, S. A., J. M. Elsen, and C. S. Haley. 1996. Methods for multiplemarker mapping of quantitative trait loci in half-sib population. Theor. Appl. Genet. 93:71-80.

Labussière, J. 1988. Review of physiological and anatomical factors influencing the milking ability of ewes and the organization of milking. Livest. Prod. Sci. 18:253-274. 
Lander, E., and L. Kruglyak. 1995. Genetic dissection of complex traits: Guidelines for interpreting and reporting linkage results. Nat. Genet. 11:241-247.

Legarra, A., and E. Ugarte. 2005. Genetic parameters of udder traits, somatic cell score, and milk yield in Latxa sheep. J. Dairy Sci. 88:2238-2245.

Maddox, J. F., K. P. Davies, A. M. Crawford, D. J. Hulme, D. Vaiman, E. P. Cribiu, B. A. Freking, K. J. Beh, N. E. Cockett, N. Kang, C. D. Riffkin, R. Drinkwater, S. S. Moore, K. G. Dodds, J. M. Lumsden, T. C. van Stijn, S. H. Phua, D. L. Adelson, H. R. Burkin, J. E. Broom, J. Buitkamp, L. Cambridge, W. T. Cushwa, E. Gerard, S. M. Galloway, B. Harrison, R. J. Hawken, S. Hiendleder, H. M. Henry, J. F. Medrano, K. A. Paterson, L. Schibler, R. T. Stone, and B. van Hest. 2001. An enhanced linkage map of the sheep genome comprising more than 1,000 loci. Genome Res. 11:12751289.

Marie-Etancelin, C., S. Casu, R. Rupp, A. Carta, and F. Barillet. 2001. New objectives of selection related to udder health, morphology and milk ability in dairy sheep. Page 4 in Proc. 52nd Ann. Meet. EAAP, Budapest, Hungary. Wageningen Acad. Publ., Wageningen, the Netherlands.

Morton, N. E. 1956. The detection and estimation of linkage between genes for elliptocytosis and the Rh blood type. Am. J. Hum. Genet. 8:80-96.
Sambrook, J., E. F. Fritsch, and T. Maniatis. 1989. Molecular Cloning: A Laboratory Manual. 2nd ed. Vol. 1, 2, and 3. Cold Spring Harbor Lab. Press, Cold Spring Harbor, NY.

SAS Institute. 1998. SAS User's Guide: Statistics. Release 6.12. SAS Inst. Inc., Cary, NC.

Schrooten, C., H. Bovenhuis, W. Coppieters, and J. A. Van Arendonk. 2000. Whole genome scan to detect quantitative trait loci for conformation and functional traits in dairy cattle. J. Dairy Sci. 83:795-806.

Visscher, P. M., R. Thompson, and C. S. Haley. 1996. Confidence intervals in QTL mapping by bootstrapping. Genetics 143:10131020.

Weller, J. I., Y. Kashi, and M. Soller. 1990. Power of daughter and granddaughter designs for determining linkage between marker loci and quantitative trait loci in diary cattle. J. Dairy Sci 73:2525-2537.

Weller, J. I., J. Z. Song, D. W. Heyen, H. A. Lewin, and M. Ron. 1998. A new approach to the problem of multiple comparisons in the genetic dissection of complex traits. Genetics 150:1699-1706. 